\title{
GREEN JOBS, A NEW MEASURE OF PUBLIC MANAGEMENT AND SUSTAINABLE DEVELOPMENT
}

\author{
ADAM SULICH${ }^{1, *}$ and TOMASZ ZEMA ${ }^{2}$ \\ ${ }^{1}$ Wroclaw University of Technology, Faculty of Computer Science and Management, Department of Infrastructure of Management, \\ ul. Smoluchowskiego 25, 50-372 Wroclaw, Poland \\ ${ }^{2}$ Wroclaw University of Technology, Faculty of Electronics, Department of Electronics, ul. Janiszewskiego 11/17, 50-372 Wroclaw, \\ Poland \\ *Corresponding author: adam.sulich@pwr.edu.pl
}

\begin{abstract}
The aim of this article is to propose a measurable definition of green jobs based on balanced, durable and sustainable development, which is an example of both the Green Economy and New Public Management (NPM) concepts. This approach is justified due to the nature of NPM, which uses the goals of management and measures of effectiveness. In this paper, the definition of green jobs is formulated as tool for measuring, based on the Polish Classification of Activities (PKD), which has roots in the classifications proposed by UN the ISIC and Eurostat NACE. Then the ease with which this tool can be used is tested by determining the efficiency of labour market institutions. Therefore, the green jobs concept can be much wider than just a qualitative description of an organisation's strategy. In this paper it is proposed that green job characteristics based on section E of PKD is more specific and because of its quantitative approach it is a suitable measurement not only in Polish conditions, but generally.
\end{abstract}

Keywords: durable and sustainable development; efficiency; green jobs; green employment

\section{Introduction}

Sustainable and durable development is a popular and very important concept, which is open to a variety of interpretations. Since the Brundtland report was published in 1987 (Bruntland Commission 1987), many researchers in universities, environmental organizations, national governments and international agencies have put forward proposals for measuring sustainable development. The quiddity of sustainable development is in balancing the relations between economy, society, space and environment and choice of its durability. The wide variety of indicators in existing national and international policy-based sets testifies to the difficulty of this challenge.

The assessment of sustainable development or green jobs is difficult, however it can achieve positive effects that can be used in other fields of science. There is an ongoing multidimensional discussion in Poland about measurement and analysis of sustainable development and its effect on the environment and economy. Evaluation is important both for scientists and governments and administration, who want to properly manage using tools of New Public Management, which allows them to manage by measuring the efficiency of undertaken actions. These trends have given rise to new calls in Poland and other European Union countries for the integration (Rutkowska-Podolowska et al. 2016) of training and development with economic development, so both can be aligned with the political economy (Scully-Russ 2013).

This discussion on the measurement of green economy goals is also visible in an international context in terms of the numerous publications, including those issued by the United Nations (Adamek 2016) on methods of measuring sustainable development. The fundamental questions are intertwined with the green economy and green jobs (Rutkowska-Podolowska et al. 2016), because they reflect the connections of sustainable development with social and financial aspects (Pearce and Atkinson 1993). However, there are very few specific indicators of how to measure, assess and evaluate sustainable development.

New Public Management and Green Economics have a common root in neo-liberalism and in the pursuit of green development (sustainable and sustainable development). Neoliberalism assumes the decentralization and liberalization of the economy through free trade, open markets, privatization, deregulation and a reduction in the role of the state. These tools are an instrument of New Public Management. At the same time, green and sustainable development presuppose decentralization and the liberalization of public authority, among other things, that "it is necessary to limit national public authority to avoid social tensions and to safeguard the fundamental freedoms and rights of individuals."

This article presents a review of what the most important sustainability and New Public Management concepts are based on and aspects of them that it may be possible to measure. For this green jobs are the chosen indicator to be analysed.

\section{Material and Methods}

The data for the years 2010-2015 presented by Central Statistical Office (GUS) were used to describe the demand of the labour market for green jobs as defined in 
the E section of Polish Classification of Activities (PKD) in the chosen region of Poland, which is Lower Silesia.

The aim of this analysis is to develop a tool for efficiently measuring green job creation as demanded by NPM. Therefore, green jobs defined as a category of $\mathrm{PKD}$, can be a factor of:

a) durability of the relations between economy, society and environment;

b) assessment of the society's needs to be satisfied in terms of the protection of the natural environment;

c) limitations on human activity in natural environments;

d) pro-ecological management.

Statistical analysis of data that conforms to the quantitative definition of green jobs that can used as an indicator of sustainable development.

\section{Sustainable Development Concept}

In the literature the development concept is widely discussed in the context of economic growth (Borys 2005). Both the economy and ecology may contribute to social welfare and incorporate some (limited) degree of sustainability. Sustainable development means that the needs of the present generation should be met without compromising the ability of future generations to meet their own needs (Bruntland Commission 1987). There are, however, reliable indications that labour, capital, and technology influence environmental production factors to such an extent that they are, in the long run, clearly unsustainable in both systems. On the other hand, the demand for certain environmental commodities and amenities (such us drinking water) clearly exceed environmental growth and production rates, and threaten environmental regeneration.

According to the Brundtland Commission (1987), sustainable development includes the concept of needs, in particular those of the world's poor, to which overriding priority should be given and the idea of a limitation imposed by the state on the effect that technology and social organizations have on the environment's ability to meet present and future needs. It is clear that as formulated by the Bruntland Commission sustainable development is more inspirational than practical and neither precise or measurable (Thwink.org 2017).

The concept of sustainable development is not a novel aspect in the evolution of economic thinking. The wish to take account of the needs of future generations while, at the same time, aiming to satisfy the needs of present generations refers essentially to the opportunity of taking account of objectives in both the long and medium terms. However, it is evident that sustainable development currently faces an imbalance when it comes to its three main pillars: economic, social and environmental. The debate has broadened to include more concern for the social dimensions of sustainable development (Scul-
ly-Russ 2013). Also, there exists a challenge to treating them equally and a search for ways to achieve the goal of sustainable development for all and promote this as the main gap that has to be filled in order to make the world a safer place. Sustainability and justice are the central policy issues of the twenty-first century and are associated with an even greater challenge: that of finding the political tool to implement solutions (Hess 2012). Therefore, measurement is important for management and planning of sustainable development and the balance of all three pillars (Fig. 1).

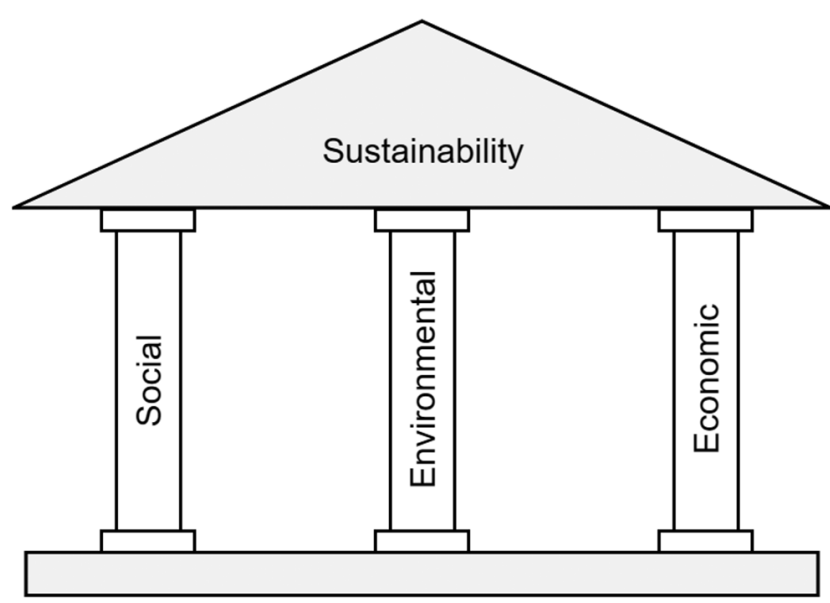

Fig. 1 The three pillars of sustainability. Source: (Thwink.org 2017).

Sustainability is the ability to continue a defined behaviour for an unlimited or unspecified period of time in order to maintain a high quality of life (Fig. 1). Therefore, environmental sustainability is the ability to maintain rates of harvesting renewable resources, producing pollution and depletion of non-renewable resources that can be continued and are durable. Secondly, economic sustainability is the ability to support a defined level of economic production indefinitely. Then social sustainability is the ability of a social system, such as country, to function at a defined level of social well-being.

The scientific outlook on development sees development as its top priority, putting people first and at its core (Table 1) comprehensive, balanced and sustainable development as its basic requirement and overall consideration as its fundamental approach. Its methods are to integrate urban and rural development, regional development, economic and social development, harmonious development between man and nature, domestic development and opening up to the outside world. Its important goals are to make sure that the aims and outcomes of all the work of the state are to realize, safeguard and expand the fundamental interests of the overwhelming majority of the people, respect the principal position of the people, give play to their creativity, protect their rights and interests, and promote their all-round development and social progress (United Nations 1992).

As presented in Table 1, sustainability is related to the quality of life in a community, that is, whether the eco- 
nomic, social and environmental systems that make up the community will provide a healthy, productive, meaningful life for all community residents, present and future.

Understanding the three parts and their links is key to understanding sustainability, because sustainability is about more than just the quality of life. It is about understanding the connections between and achieving balance among the social, economic and environmental aspects of a community.

Table 1 Two main streams of sustainable development.

\begin{tabular}{|l|l|}
\hline Conformity of axiological foundations & $\begin{array}{l}\text { Elements of sustainable } \\
\text { development }\end{array}$ \\
\hline Defined concept of the quality of life & Sustainability \\
\hline $\begin{array}{l}\text { Defined concepts of social, economic } \\
\text { and environmental development }\end{array}$ & Durability \\
\hline Defined concept of instruments & Balance \\
\hline
\end{tabular}

Source: author's own elaboration based on Sulich (2017).

\section{Green Economy}

There is no internationally agreed definition of green economy and there are at least eight separate definitions used in recent publications. For example, UNEP has defined the green economy as "one that results in improved human well-being and social equity, while significantly reducing environmental risks and ecological scarcities. It is low carbon, resource efficient, and socially inclusive" (UNEP 2011). This definition is cited in a number of more recent reports, including those of UNEMG and the OECD. Another definition of green economy offered by the Green Economy Coalition (a group of NGOs, trade union groups and others doing grassroots work on a green economy) succinctly defines green economy as "a resilient economy that provides a better quality of life for all within the ecological limits of the planet" (UNEP 2011). Implementation of a green economy can have a significant effect on the human society by:

a) eradicating poverty and hunger through targeted measures to alleviate and eliminate poverty, and enhancing agricultural production capacities and food security;

b) implementing innovation-driven development strategies and generating momentum for sustainable, healthy and stable economic growth;

c) advancing industrialization to inject impetus to coordinated development between urban and rural areas and among the three dimensions of sustainable development;

d) improving social security and social services to ensure equal access to basic public services;

e) safeguarding equity and social justice to improve people's well-being and promoting all-round human development;

f) protecting the environment and building protective barriers for eco-security; g) addressing climate change actively and integrating the response to climate change into national development strategies;

h) promoting efficient utilization of resources and sustainable energy;

i) improving national governance and ensuring economic and social development in line with the rule of law. Green Economics covers two aspects. The first is the promotion and implementation of pro-ecological processes across the whole economy, i.e. the reduction of energy and resource consumption and emissions of all pollutants, in order to ultimately achieve the separation of economic activity from pollutant emissions and resource use. Second, a greater share of the green economy across the economy by using green technologies, green energy and low-energy industries to ensure good human health and environment throughout the economic system.

In 2012, the United Nations Conference on Sustainable Development Rio +20 was held, which focused on the concept of green economy. The international debate has highlighted the need for a new definition of economic principles and the adoption of a new model of socio-economic development called green growth or green economy. Furthermore, it was acknowledged that, in view of the threats posed by human activity, sustainable development and the green economy are the only acceptable alternatives to the brown economy.

With governments today seeking effective ways of leading their nations out of these related crises whilst also taking into account these planetary boundaries, green economy (in its various forms) is proposed as a means for catalysing renewed national policy development and international cooperation and support for sustainable development. The concept has received significant international attention over the past few years as a tool to address the 2008 financial crisis as well as one of two themes for the 2012 UN Conference on Sustainable Development $(\mathrm{Rio}+20)$. This has resulted in a rapidly expanding literature including new publications on green economy from a variety of influential international organisations, national governments, think tanks, experts, non-government organisations and others.

Green Economy is a factor that generates structural changes in economic and social life. A new direction of change is the introduction of environmental criteria into production processes, investment and consumption, which in turn leads to the growth of the green economy, to green growth expressed in the growing share of the green economy in the creation of gross domestic product and green jobs. The green economy ensures that everyone who is willing to work can find a good job for themselves. Green Economy strives to balance the problems of socio-economic development, anthropogenic changes in the environment and demographic and environmental changes that have intensified in the 21 st century. It is therefore believed that green economy best expresses all three aspects of sustainable economic, social and 
environmental development. This economy is aimed at improving people's well-being while reducing ecological risk and scarcity of natural resources. Continuous social development and progress (understood as ongoing modernization) aim to control the environment through scientific progress and technology and the rational management of public institutions, which in turn accelerate the development of human civilization. This development, as already proposed in 1987, should be based on sustainable development, which is also to meet intergenerational needs

Table 2 Green economy versus modern brown economy.

\begin{tabular}{|l|l|}
\hline Brown economy & Green economy \\
\hline "Unlimited" economic growth & $\begin{array}{l}\text { Separating economic growth } \\
\text { from the consumption of } \\
\text { natural resources }\end{array}$ \\
\hline Non-renewable energy sources & Renewable energy sources \\
\hline $\begin{array}{l}\text { Intensive consumption of natural } \\
\text { resources } \\
\text { (energy and material-intensive) }\end{array}$ & Energy efficiency \\
\hline Greenhouse gas emissions & Clean production \\
\hline Destruction of biodiversity & Biodiversity protection \\
\hline Global social inequalities & $\begin{array}{l}\text { Intergenerational and interre- } \\
\text { gional justice }\end{array}$ \\
\hline $\begin{array}{l}\text { Unlimited consumption (over } \\
\text { consumption) }\end{array}$ & Sustainable consumption \\
\hline $\begin{array}{l}\text { Lack of Corporate Social Responsi- } \\
\text { bility of Businesses and Investors }\end{array}$ & $\begin{array}{l}\text { Corporate Social Responsibili- } \\
\text { ty of Businesses and Investors }\end{array}$ \\
\hline Weakening of social trust & Increase in social trust \\
\hline
\end{tabular}

Source: authors' own elaboration based on Ryszawska (2013).

\section{New Public Management}

The New Public Management (NPM) is nothing more than a set of almost every management tool found to be suitable for the public-sector. NPM is practically evaluated, however this concept is far more than a management system or a performance measurement.

The bureaucratic model of management worked exceedingly well for its time, but times have changed and a new approach to management, emphasizing teams and customer service, has emerged to challenge the traditional model of public administration. The reforms of market models take place against the traditional models of public administration as alternative models.

The shift from bureaucratic administration to business-like professional management with NPM was promoted as a strategy fitting for all levels, and branches of the public-sector, local as well as central governments, and every kind of administrative culture in any country whatsoever. NPM has been presented as a remedy to cure management ills in various organizational contexts, as well as in various areas of policy making, from education to healthcare.
The establishment of sustainable development indicators has been for many countries and institutions a key opportunity to move environmental issues higher up the policy agenda alongside economic and social issues within the frame of NPM. The sustainable development indicators have also been instrumental in promoting the concept in a much clearer way than can be achieved through national sustainable development strategies.

In many cases the relationship between indicators and policy is very strong, with the policy framework in effect determining the indicators. While there may be concerns about having indicators closely aligned with policy and hence potentially biased towards particular policy priorities at the expense of other aspects of sustainable development, this is also one of their strengths. Policy makers see them as being directly relevant to the policies they have established and effective for communication.

Within the European Union, at least, there has been some inevitable convergence among the national indicators used. This is for two reasons. Firstly, and most obviously, as newer member states develop their indicator systems, they are likely to be influenced by the indicators adopted at the European Union level. Secondly, and less obviously, the indicators used by the European Union itself have been developed through engagement with older member states and those with well-established national indicator sets have been influential in the direction taken by the European Union.

New Public Management uses primarily legal acts that help implement the principles of Green Economics. In 2010, the European Commission announced a communication entitled "Europe 2020 Strategy for smart, sustainable and inclusive growth", which includes three interrelated priorities:

a) smart development: the development of a knowledgeand innovation-based economy;

b) sustainable development: supporting a resource efficient, more environmentally friendly and more competitive economy;

c) inclusive growth: supporting a high employment economy, ensuring social and territorial cohesion.

It is characterized by a government that uses NPM to develop a leading role and wider public participation, with the aim of improving the quality of life of the poor and increase their capacity for employment and entrepreneurship. To meet this end, the poor labour force is provided with a vocational education, entrepreneurship training and practical training in agricultural techniques. They are encouraged to seek new jobs or start their own businesses. Young farmers in poor areas are offered assistance when they encounter difficulties in employment and entrepreneurship, with an ultimate goal of growth in production, employment transfer, income increase and economic growth in poverty-stricken areas (OECD 2001).

NPM reforms, if they are to be effectively implemented, require a holistic approach, integrating the multiple 
human resources, financial, technical and structural factors involved within a dynamic environment. Green activities are key actions of policy makers in countries and regions across the world that can be created in almost all sectors of economy, which help in the sustainable development leading to a greening of the economy and are an important tool for countering unemployment.

Table 3 They key differences between the Weberian model and New Public Management.

\begin{tabular}{|l|l|}
\hline Classic (Weberian) model & New Public Management \\
\hline $\begin{array}{l}\text { Hierarchy and functional struc- } \\
\text { ture (machine like, rigid and } \\
\text { impersonal) }\end{array}$ & $\begin{array}{l}\text { None rigid/pure model of admin- } \\
\text { istration Initiatives from bottom } \\
\text { of the structure }\end{array}$ \\
\hline $\begin{array}{l}\text { Professionalism and specialisa- } \\
\text { tion }\end{array}$ & $\begin{array}{l}\text { Managerialism } \\
\text { than self (bureaucracy) }\end{array}$ \\
\hline Work division & Cost control and efficiency \\
\hline Political accountability & $\begin{array}{l}\text { Measures the effects based on } \\
\text { achieving the goals }\end{array}$ \\
\hline Administrative man & $\begin{array}{l}\text { Healthy competition, democracy } \\
\text { in public administration }\end{array}$ \\
\hline Realization of processes & $\begin{array}{l}\text { Oriented processes to perfection } \\
\text { Client oriented }\end{array}$ \\
\hline $\begin{array}{l}\text { Centralisation of power - differ- } \\
\text { entiation }\end{array}$ & $\begin{array}{l}\text { Decentralisation } \\
\text { Efficiency - regard for personnel }\end{array}$ \\
\hline Bounded rationality & High quality services \\
\hline Public-Private distinction & Public - Private partnership \\
\hline
\end{tabular}

Source: authors' own elaboration.

\section{Green Jobs}

Green jobs should be objective and measurable and this second part is the most difficult for researchers and statistic offices around the world. Assessing the importance of green jobs can be an effective tool for assessing sustainable development, hence it was not previously proposed as an indicator by Eurostat, OECD and UN (UN 2008).

Green jobs are places of employment that contribute to preserving or restoring the environment in traditional sectors, such as manufacturing and construction, or in new, emerging sectors such as renewable energy and energy efficiency (Rutkowska-Podołowska et al. 2016). Moreover, green jobs are a solution for young, unemployed people who not only can find employment but can become entrepreneurs in this sector of the economy.

The United Nation's Environmental Programme (UNEP), which provides worldwide leadership on improving the environment, sees a dual promise in the green economy to protect the environment and provide decent work for the world's poor (Renner et al. 2008).

A green job is any job or self-employment that genuinely contributes to a more sustainable world. At the en- terprise level, green jobs can produce goods or provide services that benefit the environment, for example green buildings or clean transportation. For persons beginning their professional career, the meaning and potential of green places for employment is very high (Sulich 2017).

Based on sustainable development a distinction can be drawn between employment in green economic sectors from an output perspective and job functions in all sectors from an environmentally friendly process perspective. For the ILO (2016), green jobs are all those jobs that fall in the dashed area in Fig. 2.

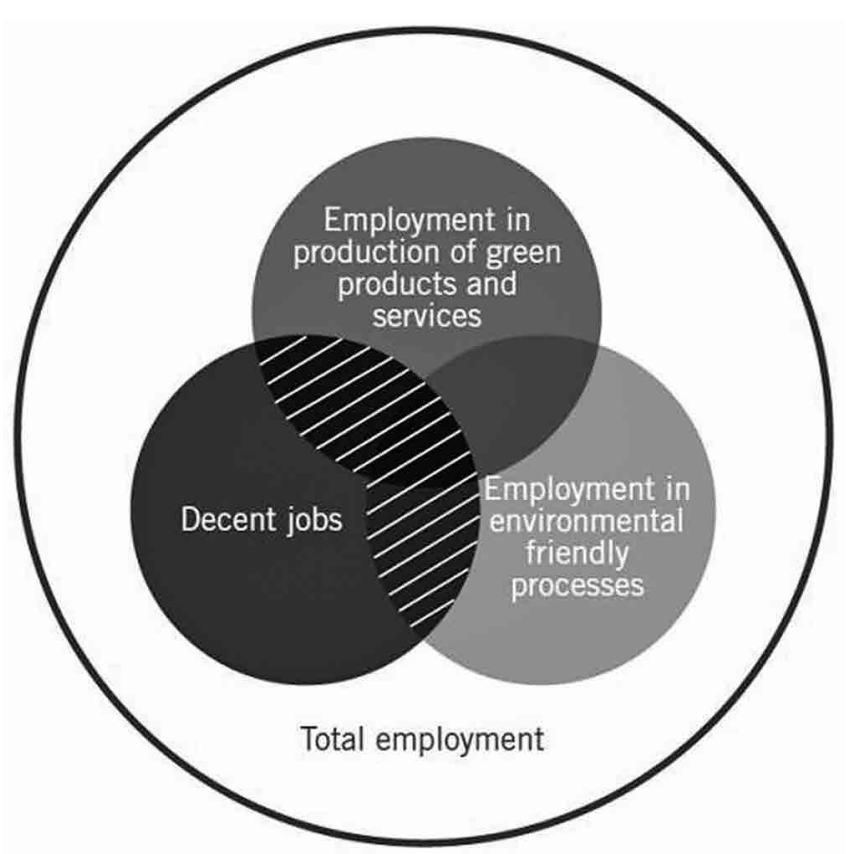

Fig. 2 The green jobs. Source: (ILO 2016).

The concept of green jobs emerged from the so-called green economy, which assumes that green jobs will emerge thanks to new economic paradigms. They will reduce unemployment and prevent the degradation of the environment.

The topic of green jobs is important both for the protection of the environment and the labour market. It represents one of the benefits of sustainable development. One of the objectives of the European Union is to ensure a balance between economic growth and environmental protection.

There are many definitions of the concept of green jobs in the national and international literature. In general, they can be defined as workplaces that support the environment (Popławski et al. 2017). The definition focused on the result of human action defines green jobs as: "jobs in businesses that produce goods or provide services that benefit the environment or conserve natural resources". Another approach includes more processes and states that green jobs are: “jobs in which workers' duties involve making their establishment's production processes more environmentally friendly or use fewer natural resources". The concept of green jobs implies, in 
addition to the principles of sustainable development, the fight against unemployment by creating decent jobs. Based on these two approaches it is possible to measure and identify categories of green jobs based on the Polish Classification of Activities (Pol. Polska Klasyfikacja Działalności, PKD) in Table 4. The PKD is based on the ISIC proposed by the UN and UE standards of the NACE (PKD 2007). The Polish Classification of Activities is an example of national classifications that are used to register a company in Europe, and this classification consists of the same sections and groups as ISIC or NACE classifications. All the mentioned systems of classification are comparable, and allow a comparative study of different activities in different countries. Presented in Table 4 section $\mathrm{E}$ is only an example of the quantitative approach to measuring green jobs the qualitative definition of which is formulated above.

Section $\mathrm{E}$ was chosen because of the availability of statistical data and its description (characteristic) most closely matches the definitions of most of green jobs. The quantitative definition of green jobs can be extended to other PKD sections, but then there must be a more rigorous selection of the groups, because, for example section A - agriculture and forestry, include activities that are very destructive of the environment and therefore cannot be classified as green jobs.

Table 4 Green jobs based on the E category of PKD.

\begin{tabular}{|l|c|l|}
\hline PKD section & $\begin{array}{c}\text { PKD } \\
\text { group }\end{array}$ & PKD description of group \\
\hline \multirow{2}{*}{$\begin{array}{l}\text { E- water supply; } \\
\text { sewerage, waste } \\
\text { management } \\
\text { and remediation } \\
\text { activities }\end{array}$} & 36.0 & $\begin{array}{l}\text { Collection, purification and distribution } \\
\text { of water }\end{array}$ \\
\cline { 2 - 3 } & 38.0 & Sewage disposal and treatment \\
\cline { 2 - 3 } & 38.2 & Waste collection \\
\cline { 2 - 3 } & 39.0 & Waste treatment and disposal \\
\hline & $\begin{array}{l}\text { Remediation activities and other } \\
\text { service activities related to waste } \\
\text { management }\end{array}$ \\
\hline
\end{tabular}

Source: authors own interpretation based on PKD (2007).

The number of green jobs that come within the E section of PKD in Poland grows each year by about $1 \%$ per year (Table 5). A significant number of green jobs have been created in Lower Silesia in Poland (Table 6). In comparison with the whole country these numbers are not impressive, but in comparison with the creation of all new jobs these numbers are significant in this region for the New Public Management of the green jobs policy in the local labour market.
Among all the 16 provinces in Poland there is one for which the green jobs labour market has been further analysed (Sulich 2017). This study indicates that in this particular province there is a stable and growing demand for green jobs. Moreover, in this province in 2010-2016 $25 \%$ of young people were first employed doing green jobs (Popławski et al. 2017).

Table 6 Number of green jobs in the chosen province in Poland.

\begin{tabular}{|l|c|c|c|c|c|c|c|}
\hline \multirow{2}{*}{$\begin{array}{l}\text { Name of } \\
\text { province }\end{array}$} & \multicolumn{6}{|c|}{ Number of work places in E section of PKD } \\
\cline { 2 - 8 } & 2010 & 2011 & 2012 & 2013 & 2014 & 2015 & 2016 \\
\hline Lower Silesia & 1081 & 624 & 896 & 1104 & 781 & 586 & 641 \\
\hline
\end{tabular}

Source: authors own interpretation based on BDL (2017).

Indicators connected with the definition based on PKD are more specific and easy to measure, both as number of unemployed or employed, in this specific section. These are traditional measures of communities. All statistical offices use numbers to show progress, but the traditional numbers only show changes in one part of the community without showing the many links between the community's economy, society and environment. Rather than a piecemeal approach, there is a need for a holistic view of the community that takes into account the links between the economy, the environment and society ( $\mathrm{Ta}$ ble 3). Therefore, it is possible to take actions to improve conditions in a sustainable community that take these connections into account. Indicators of sustainability are different from traditional indicators of economic, social, and environmental progress. Traditional indicators measure changes in one part of a community as if they were entirely independent of the other parts. Sustainability indicators reflect the reality that the three different segments are very tightly interconnected.

Table 7 Traditional and sustainable indicators related to the labour market.

\begin{tabular}{|c|c|c|}
\hline $\begin{array}{l}\text { Traditional } \\
\text { Indicators }\end{array}$ & $\begin{array}{l}\text { Sustainability indi- } \\
\text { cators }\end{array}$ & $\begin{array}{l}\text { Emphasis of Sustaina- } \\
\text { bility Indicators }\end{array}$ \\
\hline $\begin{array}{l}\text { Unemployment } \\
\text { rate }\end{array}$ & $\begin{array}{l}\text { Variability of skill levels } \\
\text { required for jobs }\end{array}$ & \multirow{2}{*}{$\begin{array}{l}\text { Resilience of the job } \\
\text { market }\end{array}$} \\
\hline \multirow{2}{*}{$\begin{array}{l}\text { Number of } \\
\text { companies }\end{array}$} & $\begin{array}{l}\text { Number and variability } \\
\text { in size of companies }\end{array}$ & \\
\hline & $\begin{array}{l}\text { Number and variability } \\
\text { in the types of industry }\end{array}$ & \multirow{3}{*}{$\begin{array}{l}\text { Ability of the job } \\
\text { market to be flexible } \\
\text { in times of economic } \\
\text { change }\end{array}$} \\
\hline \multirow[t]{2}{*}{ Number of jobs } & $\begin{array}{l}\text { Diversity and vitality of } \\
\text { local job base }\end{array}$ & \\
\hline & Number of green jobs & \\
\hline
\end{tabular}

Source: author's own interpretation based on Sustainable Measures (2017).

Table 5 Employment changes in E section of PKD in Poland.

\begin{tabular}{|l|c|c|c|c|c|c|c|}
\hline Year & $\mathbf{2 0 1 0}$ & $\mathbf{2 0 1 1}$ & $\mathbf{2 0 1 2}$ & $\mathbf{2 0 1 3}$ & $\mathbf{2 0 1 4}$ & $\mathbf{2 0 1 5}$ & $\mathbf{2 0 1 6}$ \\
\hline Number of employed & 142,096 & 144,411 & 145,603 & 146704 & 147,738 & 149,909 & 151,230 \\
\hline
\end{tabular}

Source: authors own interpretation based on BDL (2017). 
These indicators correspond to the postulates formulated by the Institute for Sustainable Development and experts from the European Commission. The ratio of new green jobs to all new jobs created in the national labour market or registered unemployment rate can be a national indicator. The effect of green jobs on the unemployment rate is confirmed, for example, by Eurostat statistics.

\section{Conclusions}

There is a need for quantitative indexing using relatively simple information and diagnostic tools for developing new paradigms. At present, the indicators no longer require more justification, and the premises of Polish research on the measurement of sustainable development are very close to the motives of research in other countries. In addition, these indicators serve the implementation of international environmental and environmental management and social, economic and environmental governance in such a way as to ensure a high quality of life by respecting the principle of intergenerational justice and the principle of sustainability not only for the natural environment. This article points out the economic importance of green jobs as a new indicator for assessing sustainable development and precisely defining what is a green job category based on the Polish PKD.

The proposals presented in this paper have revolved around two main themes; green economy and New Public Management that have normative, operational and monitoring roles for green jobs. Based on them it is possible to consider the ways to strengthen the framework for sustainable development. While economic wealth is an important measure of sustainable development from the capital perspective, it cannot stand alone. It must be supplemented to form a practical and complete indicator set.

Presented in this paper green jobs are not intended as an international recommendation, but as a research proposal worthy of consideration by countries interested in finding a conceptually clear and defensible basis for indicators of sustainable development that is focused on long-term well-being.

\section{REFERENCES}

Adamek P (2016) Consequences of Corporate Social Responsibility Approach in Voluntary European and Global "Responsible” Initiatives. In: Kovářová E, Melecký L, Staníčková M (eds) Proceedings of the 3rd International Conference on European Integration 2016, ICEI 2016, May 19-20, 2016, Ostrava, Czech Republic, pp 19-27.

BDL, Bank Danych Lokalnych (2017) Rynek pracy, https://bdl.stat .gov.pl/BDL/metadane/cechy/szukaj?slowo=rynek\%20pracy\#. Accessed 10 March 2017.
Borys T (2005) Zrownowazony rozwoj jako przedmiot pomiaru wskaznikowego. In: Borys T (ed) Wskazniki zrownowazonego rozwoju, Wydawnictwo Ekonomia i Srodowisko, Warszawa-Bialystok (in Polish).

Brundtland Commission (1987) Report of the World Commission on Environment and Development. United Nations. http:// www.un-documents.net/our-common-future.pdf. Accessed: 2 March 2017.

Hess D J (2012) Good Green Jobs in a Global Economy. The MIT Press, London, UK.

ILO International Labour Office (2016) What is a green job? http:// www.ilo.org/global/topics/green-jobs/news/WCMS_220248 /lang--en/index.htm Accessed 22 May 2017.

OECD (2001) Policies to Enhance Sustainable Development, Meeting of the OECD Council at Ministerial Level, https:// www.oecd.org/greengrowth/1869800.pdf. Accessed 25 May 2017.

Pearce DW, Atkinson GD (1993) Capital theory and the measurement of weak sustainable development: an indicator of "weak" sustainability. Ecol Econ 8: 103-108.

PKD, Polska Klasyfikacja Działalności (2007) http://stat.gov .pl/Klasyfikacje/doc/pkd_07/pkd_07.htm. Accessed: 5 May 2017.

Popławski Ł, Rutkowska M, Sulich A (2017) Protected areas and green jobs versus environmental goods and services sector competitive analysis. In: Lekkas et al. (eds) 15th International Conference on Environmental Science and Technology, CEST 201731 August-2 September 2017, Rhodes, Greece.

Renner M, Sweey S, Kubit J (2008) Green jobs: Towards Decent Work in sustainable low-carbon World, UNEP, Nairobi.

Rutkowska-Podołowska M, Sulich A, Szczygieł N (2016) Green jobs. In: Kováŕová E, Melecký L, Staníčková M (eds) Proceedings of the 3rd International Conference on European Integration 2016, ICEI 2016, May 19-20, 2016, Ostrava, Czech Republic.

Ryszawska B (2013) Koncepcja zielonej gospodarki jako odpowiedź na kryzys gospodarczy i środowiskowy. Prace Naukowe Uniwersytetu Ekonomicznego we Wrocławiu 318: 48.

Scully-Russ E (2013) The Dual promise of green jobs: A qualitative study of federally funded energy training programmes in the USA. European Journal of Training and Development, 37: 257-272.

Sulich A (2017) Zielone miejsca pracy - diagnoza sytuacji studentów i absolwentów Politechniki Wrocławskiej. Studia Ekonomiczne. Zeszyty Naukowe Uniwersytetu Ekonomicznego w Katowicach 315: 139-149.

Sustainable Measures (2017) Traditional vs. sustainability indicators. http://www.sustainablemeasures.com/node/90. Accessed 02 May 2017.

Thwnik.org (2017) Sustainable Development. http://www.thwink .org/sustain/glossary/Sustainability.htm. Accessed 02 May 2017.

United Nations UN (2008) Measuring sustainable development, Report of the Joint UNECE/OECD/Eurostat Working Group on Statistics for Sustainable Development, United Nations New York and Geneva.

UNEP (2011) Green economy report http://web.unep.org/greeneconomy/resources/green-economy-report. Accessed 14 October 2017.

United Nations (1992) Agenda 21 United Nations Conference on Environment \& Development Rio de Janerio, Brazil, 3 to 14 June 1992. https://sustainabledevelopment.un.org/content /documents/Agenda21.pdf. 